\title{
IMPLEMENTASI PRINSIP SYARIAH DALAM PENGIKATAN HAK TANGGUNGAN PADA PEMBIAYAAN MUSYARAKAH DI PT BANK NEGARA INDONESIA SYARIAH KOTA BANDA ACEH
}

\author{
MUARIF
}

\author{
Program Studi Magister Kenotariatan \\ Fakultas Hukum Universitas Sumatera Utara \\ Jalan Dr. T. Mansur Nomor 9, Kampus Padang Bulan, Medan \\ Telp.(061)8211633, Email: muarifarif11@gmail.com
}

\begin{abstract}
Financing agreement develops in the community. Mortgage rights have become an essential need to guarantee that debt settlement will be pursuant to the agreement. The research problems are how about the legal provisions concerning mortgage rights in Musharakah according to the laws and regulations prevailing in Indonesia, how sharia principles in mortgage rights binding in Musharakah Financing are implemented at PT BNI Syariah in Banda Aceh, and how about the legal consequences resulted from mortgage rights binding in Musharakah Financing at PT BNI Syariah in Banda Aceh. The theories applied in this research are Theory of Legal Protection and Theory of Social Justice (Kemaslahatan). It employs normative juridical approach which is analytically descriptive. The research materials consist of secondary and tertiary legal materials. The data collection technique used is library study. The results demonstrate that according to Law No. 4/1996 on Mortgage Rights over land, hereinafter is referred to as Mortgage Rights, it is the collateral that is charged to land titles as stipulated in Law No. 5/1960 on Basic Agrarian Principles. It is also demonstrated that sharia principles have all been implemented in Musharakah Financing whereas some of sharia principles are already implemented in mortgage rights binding and some others are not implemented yet.
\end{abstract}

Keywords:Mortgage Right, Musharakah Financing, Collateral

\section{Intisari}

Perjanjian Pembiayaan yang berkembang dimasyarakat, Hak Tanggungan menjadi suatu kebutuhan penting menjamin dilaksanakan prestasi sesuai dengan perjanjian, dari latar belakang tersebut dapat diambil rumusan masalah antara lain, bagaimana ketentuan hukum Pengikatan Hak Tanggungan dengan Musyarakah menurut peraturan perundang-undangan di indonesia, bagaimana implementasi Prinsip-Prinsip syariah dalam Pengikatan Hak Tanggungan pada Pembiayaan Musyarakah PT BNI Syariah di kota Banda Aceh, bagaimana Akibat Hukum dalam Pengikatan Hak Tanggungan pada Pembiayaan Musyarakah PT BNI Syariah di Kota Banda Aceh, Teori dipergunakan dalam penelitian ini Teori Perlindungan Hukum dan Teori Kemaslahatan, Penelitian ini dilakukan dengan menggunakan metode pendekatan yuridis normatif dan bersifat deskriptif analitis. Bahan penelitian yang digunakan terdiri dari bahan hukum sekunder dan bahan hukum tersier. Teknik pengumpulan data dilakukan dengan cara studi kepustakaan. Hasil pembahasan dari Rumusan masalah dalam Penelitian ini Menurut Undang-Undang Nomor 4 Tahun 1996 Hak Tanggungan atas tanah 
yang selanjutnya disebut Hak Tanggungan (HT), adalah jaminan yang dibebankan pada hak atas tanah sebagaimana sebagaimana dimaksud dalam Undang-Undang Nomor 5 Tahun 1960 tentang peraturan dasar pokok agraria, pada Prinsip Syariah dalam Pembiayaan Musyarakah sudah terimplementasi semua sedangkan Prinsip Syariah dalam Pengikatan Hak Tanggungan sebagian sudah terimplementasi sebagiannya lagi belum terimplementasi, Akibat Hukum kepada pihak yang menjamin untuk membantu nasabah dalam menyelesaikan Pembiayaan, Akibat Hukum kepada pihak yang meminta Jaminan untuk meringankan beban Masyarakat ekonomi lemah, Akibat Hukum terhadap Objek Jaminan tanah dan Bangunan yang diikatkan Hak Tanggungan akan sementara menjadi milik Bank yang memberikan kredit, sehingga apabila terjadi kredit macet Bank berhak mengeksekusi objek jaminan dengan cara dilelang.

Kata Kunci : Hak Tanggungan, Pembiayaan Musyarakah, Jaminan.

\section{A. Latar Belakang}

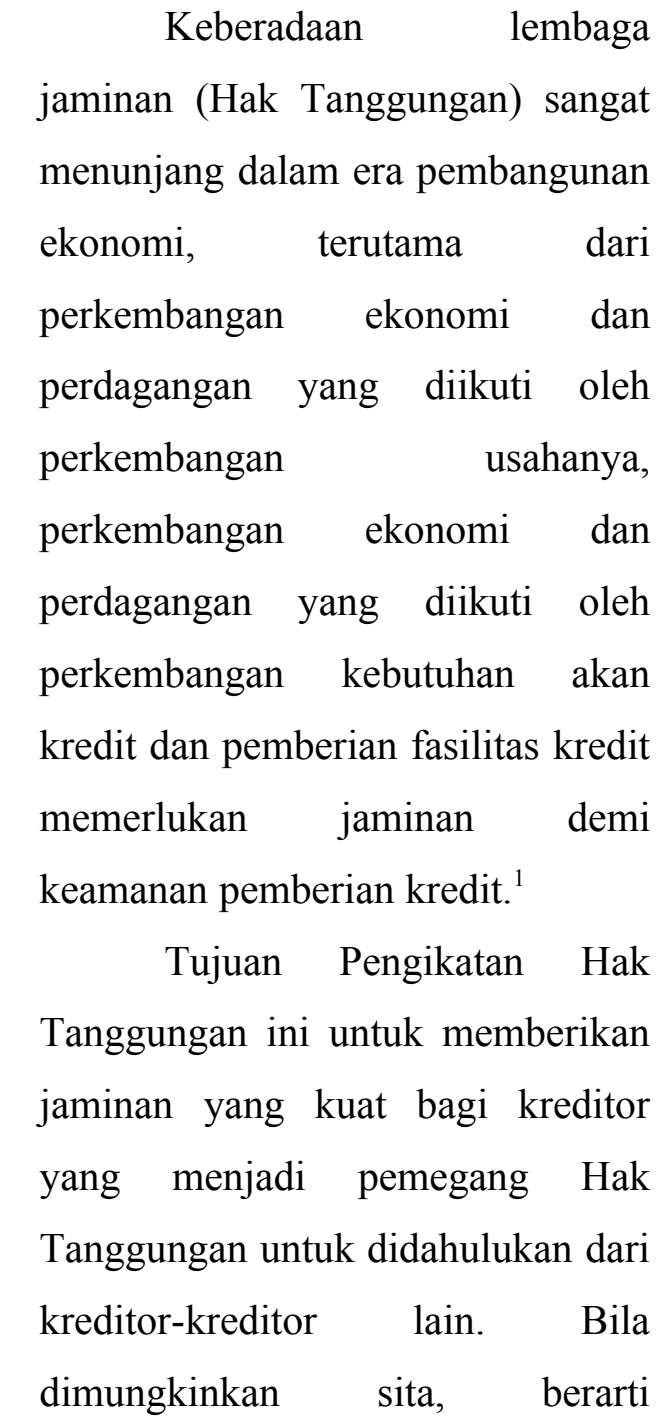

${ }^{1}$ Nurjannah ST, Eksistensi Hak Tanggungan Sebagai Lembaga Jaminan Hak Atas Tanah (Tinjauan Filosofis), jurnal Universitas Islam Negeri (UIN) Alauddin Makassar, 2018, h. 195. pengadilan mengabaikan bahkan meniadakan kedudukan yang diutamakan dari kreditor pemegang Hak Tanggungan. Undang-Undang Hak Tanggungan adalah hak istimewa yang memberikan kedudukan yang diutamakan bagi pemegang hak tanggungan, meskipun debitur wanprestasi pemegang hak tanggungan tetap dapat mengeksekusi objek hak tanggungan berdasarkan kekuatan eksekutorial yang disebuut dengan parate eksekusi dan menjual objek hak tanggungan dihadapan masyarakat umum dan mengambil hasilnya untuk melunasi hutang debitor. $^{2}$

\footnotetext{
${ }^{2}$ Tesis Saraswati Jaya, Perlindungan Hukum Terhadap Bank Sebagai Kreditor Pemegang Hak Tanggungan Dalam Penangguhan Eksekusi Jamiman Berkaitan UU No 37 Tahun 2004 Tentang Kepailitan, Program Studi Magister Kenotariatan , Sekolah Pasca Sarjana, Universitas Sumatera Utara, Medan, 2008, h.45
} 
Kedudukan pemegang hak tanggungan tetap sebagai kreditur preferen meskipun debitur dinyatakan pailit, bank tetap dapat menjual objek hak tanggungan dihadapan umum dan tidak terpengaruh oleh keputusan paillit. ${ }^{3}$ Hak Tanggungan menurut ketentuan Pasal 1 butir 1 Undang-Undang Nomor 4 Tahun 1996 tentang Hak Tanggungan Atas Tanah Beserta Benda-Benda yang berkaitan dengan tanah, adalah "Hak Tanggungan atas tanah beserta benda-benda yang berkaitan dengan tanah, yang selanjutnya disebut Hak Tanggungan, adalah hak jaminan yang dibebankan pada hak atas tanah sebagaimana dimaksud dalam Undang-Undang Nomor 5 Tahun 1960 tentang Peraturan Dasar Pokok-Pokok Agraria, berikut atau tidak berikut benda-benda lain yang merupakan satu kesatuan dengan tanah itu, untuk pelunasan utang tertentu, yang memberikan kedudukan yang diutamakan kepada kreditur tertentu terhadap krediturkreditur lain".

$$
\text { Dalam }
$$$$
\text { perjanjian }
$$

Pembiayaan yang berkembang dimasyarakat, Hak Tanggungan menjadi suatu kebutuhan penting menjamin dilaksanakan prestasi sesuai dengan perjanjian, problematikanya adalah bagaimana pengaturan Hak Tanggungan dengan objek tanah yang belum bersertifkat dan bagaimana pelaksanaan Hak Tanggungan dengan objek tanah yang belum bersertifikat, penelitian ini bertujuan untuk mengkaji dan menganalisis pengaturan dan pelaksanaan Hak Tanggungan dengan objek tanah yang belum bersertifikat, dan dapat disimpulkan bahwa dalam pelaksanaan terdapat kesenjangan antara peraturan mengenai pembebanan Hak Tanggungan dengan objek hak atas tanah yang belum bersertifikat dengan pelaksanaan dilapangan. ${ }^{4}$

\section{B. Perumusan Masalah}

Berdasarkan uraian diatas, maka permasalahan yang dianalisis dalam penelitian ini adalah sebagai berikut:

1. Bagaimana Ketentuan Hukum Pengikatan Hak Tanggungan dengan Musyarakah menurut peraturan Perundang-Undangan di Indonesia?

4 Hasil wawancara dengan Ichwan Hassafa, processing, di PT BNI Syariah Banda Aceh, Selasa 18 Agustus 2019, jam 10.00 WIB. 
2. Bagaimana Implementasi Prinsip-Prinsip Syariah dalam Pengikatan Hak Tanggungan pada Pembiayaan Musyarakah PT BNI Syariah di Kota Banda Aceh?

3. Bagaimana Akibat Hukum dalam Pengikatan Hak Tanggungan pada Pembiayaan Musyarakah PT BNI Syariah di Kota Banda Aceh?

\section{Metode Penelitian}

Berdasarkan perumusan masalah dalam menyusun penelitian ini, jenis penelitian yang digunakan adalah jenis penelitian yuridis normatif. Sifat penelitian ini ialah deskriptif. Sumber bahan hukum yang digunakan adalah data sekunder dengan bahan hukum primer, bahan hukum sekunder dan bahan hukum tersier. Sifat penelitian ini adalah penelitian deskriptif analitis dan penarikan kesimpulan menggunakan metode deduktif.

\section{Pembahasan}

1. Ketentuan Hukum Pengikatan Hak Tanggungan dengan Musyarakah menurut peraturan PerundangUndangan di Indonesia.

Menurut ketentuan pasal 10 ayat (3) Undang-Undang Hak Tanggungan (UUHT), tanah yang belum bersertipikat dapat dijadikan sebagai objek Hak
Tanggungan (HT), dengan syarat pendaftaran Hak Tanggungan (HT) tersebut dilakukan bersamaan dengan pendaftaran hak atas tanah yang bersangkutan. Hal ini tidak memberikan kepastian hukum bagi kreditur, karena Hak Atas Tanah harus didaftarkan terlebih dahulu baru Hak Tanggungan (HT) dapat didaftarkan. Oleh karena itu dilakukan pengkajian tentang pelaksanaan pemberian Hak Tanggungan (HT) atas tanah yang belum bersertifikat di Kota Lhokseumawe, pertimbangan Bank dan PPAT dalam menerima jaminan atas tanah yang belum bersertipikat dan akibat hukum yang timbul apabila pemberian Hak Tanggungan (HT) tersebut tidak dapat didaftarkan. $^{5}$

$$
\text { Hak Tanggungan }
$$
mempunyai sifat tidak dapat dibagibagi, yaitu bahwa jaminan meliputi benda secara utuh, artinya dengan membayar sebagian hutang tidak berarti dapat membebaskan hutang, sehingga apabila jaminan tersebut berupa tanah, maka jika sebagian hutang dilunasi tidak mewajibkan pemegang Hak Tanggungan untuk

\footnotetext{
${ }^{5}$ Tesis Rani, Aspek Hukum Joint Financing Kredit dengan Pemberian Jaminan Hak Tanggungan, Program Studi Magister Kenotariatan , Sekolah Pasca Sarjana, Universitas Sumatera Utara, Medan, 2013, h.46.
} 
menyerahkan sebagian dari tanah yang dijadikan jaminan. ${ }^{6}$

Perjanjian Hak Tanggungan

(HT) bukan merupakan perjanjian yang berdiri sendiri. Keberadaannya adalah karena adanya perjanjian lain, yang disebut perjanjian induk. Perjanjian induk bagi perjanjian Hak Tanggungan (HT) adalah perjanjian utang piutang yang menimbulkan utang yang dijamin. ${ }^{7}$ Dasar pinjaman ini adalah selama pinjaman belum dibayar lunas maka selama itu tanah milik si berutang tidak boleh dibuat perjanjian terkecuali dengan pihak si berpiutang sendiri atau dengan orang lain untuk kepentingan dan dengan persetujuan si berpiutang. ${ }^{8}$

Menurut UUPA, yang dapat dijadikan jaminan utang dengan dibebani Hak Tanggungan (HT) adalah Hak Milik, Hak Guna Usaha dan Hak Guna Bangunan. Demikian menurut pasal 25, 33, dan 39 UUPA. ${ }^{9}$

Suatu obyek Hak

Tanggungan (HT) dapat dibebani

6 M. Khoidin, Hukum Jaminan, Hak-Hak Jaminan, Hak Tanggungan, dan Eksekusi Hak Tanggungan, Laksbang Yustitia, Surabaya, 2017, h. 83.

7 Supriyadi, Dasar-Dasar Hukum Perdata di Indonesia, Kiara Science, Kudus, 2015, h. 88.

8 Rosnidar Sembiring, Hukum Pertanahan Adat, PT RajaGrafindo Persada, Depok, 2017, h. 135.

${ }^{9}$ Ibid, h. 57. dengan lebih dari satu Hak Tanggungan (HT) guna menjamin pelunasan lebih dari satu utang, apabila suatu obyek Hak Tanggungan (HT) dibebani dengan lebih dari satu Hak Tanggungan (HT), peringkat masing-masing Hak Tanggungan (HT), peringkat masing-masing Hak Tanggungan (HT) ditentukan menurut tanggal pendaftarannya pada kantor pertahanan, peringkat Hak Tanggungan (HT) yang didaftar pada tanggal yang sama ditentukan menurut tanggal pembuatan Pemberian Hak Tanggungan (HT) yang bersangkutan

Pasal 8 UUHT menentukan bahwa pemberi Hak Tanggungan (HT) adalah orang perseorangan atau badan Hukum yang mempunyai kewenangan untuk melakukan perbuatan Hukum terhadap obyek Hak Tanggungan yang bersangkutan, kewenangan untuk melakukan perbuatan Hukum terhadap obyek Hak Tanggungan sebagaimana dimaksud pada ayat (1) harus ada pada pemberi Hak Tanggungan pada saat pendaftaran Hak Tanggungan (HT) dilakukan. ${ }^{10}$

Menurut pasal 11 ayat (2) UUHT, dalam Pemberian Hak Tanggungan (HT) Op.Cit, h. 191. 
dapat dicantumkan janji-janji tertentu. Dalam pasal 11 ayat (2) UUHT ditentukan bahwa dalam Pemberian Hak Tanggungan (HT) dapat dicantumkan janji-janji,

Menurut ketentuan pasal 1171 ayat

2 KUHPerdata, kuasa untuk memasang hipotik harus dibuat dengan otentik. Di dalam pelaksanaannya (praktiknya) otentik itu adalah Notaris. Tidak demikian halnya untuk surat kuasa Membebankan Hak Tanggungan (SKMHT)

Kuasa untuk Membebankan Hak Tanggungan (HT) tidak dapat ditarik kembali atau tidak dapat berakhir oleh sebab apapun juga kecuali karena kuasa tersebut telah dilaksanakan atau karena telah habis jangka waktunya sebagaimana dimaksud pada Pasal 15 ayat 3 dan ayat 4, surat kuasa Membebankan Hak Tanggungan (SKMHT) mengenai hak atas tanah yang belum terdaftar wajib diikuti dengan pembuatan Pemberian Hak Tanggungan (HT) selambat-lambatnya 3 (tiga) bulan sesudah diberikan. ${ }^{11}$

Pengikatan jaminan terhadap benda yang tidak bergerak (tetap) berdasarkan pada Undang-Undang Nomor 4 Tahun 1996 tentang Hak Tanggungan (HT) atas tanah beserta benda-benda yang berkaitan dengan tanah, yang dalam pasal 1 ayat 1

\footnotetext{
Boedi Harsono, Hukum Agraria Indonesia, Sejarah Pembentukan Undang-Undang Pokok Agrarian Isi dan Pelaksanaanya, Djambatan, Jakarta, 2008, h. 430.
}

menentukan bahwa Hak Tanggungan (HT) atas tanah beserta benda-benda yang berkaitan dengan tanah, yang untuk selanjutnya disebut Hak Tanggungan (HT) adalah hak jaminan yang dibebankan pada hak atas tanah sebagaimana di maksud dalam Undang-Undang Nomor 5 Tahun 1960 tentang Peraturan dasar pokok-pokok agraria, berikut atau tidak berikut bendabenda lain yang merupakan satu kesatuan dengan tanah itu, untuk pelunasan hutang tertentu, yang memberikan kedudukan yang diutamakan kepada kreditor tertentu terhadap kreditur-kreditur lain.

Musyarakah merupakan bagi hasil ketika dua atau lebih pengusaha pemilik dana/modal bekerja sama sebagai mitra usaha, membiayai investasi usaha baru atau yang sudah berjalan. Mitra usaha pemilik modal berhak ikut serta dalam manajemen perusahaan, tetapi itu tidak merupakan keharusan. Para pihak dapat membagi pekerjaan mengelola ussha sesuai kesepakatan dan mereka juga dapat meminta gaji/upah untuk tenaga dan keahlian yang mereka curahkan untuk usaha tersebut.

Musyarakah diatur dengan kontrak, yang menyatakan secara terperinci mengenai aturan dan 
syarat-syaratnya. Hal ini memastikan bahwa saham modal Bank plus keuntungannya seperti yang diharapkan di dalam kontrak diberikan kepada Bank pada saat jatuh tempo, posisi Bank dalam modal Musyarakah (kas atau sejenisnya) harus diakui pada saat pembayaran kepada mitra atau ketika disetorkan kepadanya atas rekening Musyarakah, porsi ini dalam pembukuan Bank akan dibukukan dalam perkiraan Pembiayaan Musyarakah (nama Nasabah) serta akan dimasukkan dalam laporan keuangan dibawah judul "Pembiayaan Musyarakah". ${ }^{2}$

Perubahan bentuk kerjasama dapat dilakukan dengan syarat disetujui oleh para pihak yang bekerjasama, pembagian keuntungan dan atau kerugian dalam kerjasama Modal dinilai secara proporsional, apabila para pihak tidak mengenai pembagian keuntungan dan kerugian, maka keuntungan dan kerugian dibagi berdasarkan keseimbangan, sedangkan mereka yang hanya menyertakan keahliannya mendapat bagian yang sama dengan pemodal terendah. ${ }^{13}$

Jaminan yang dapat diberikan adalah benda bergerak dan benda tidak

${ }^{12}$ Hirsanuddin, Hukum Perbankan Syariah di Indonesia, Genta Press, Yogyakarta, 2008, h. 130.

${ }^{13}$ Manan Abdul, Op.Cit, h. 18. bergerak. Benda bergerak dibagi atas benda bertubuh dan benda tidak bertubuh, sementara benda tidak bergerak adalah tanah dan bukan tanah, benda bergerak bertubuh terdaftar, seperti: kapal terbang, kapal laut, dan helikopter, diikat dengan hipotik jaminan fidusia. Benda bergerak bertubuh tidak terdaftar seperti persediaan, mesin-mesin, buku permata, logam mulia, diikat dengan jaminan fidusia gadai. Sementara jaminan tidak bergerak, yaitu tanah, tanah ada yang terdaftar dan ada yang tidak terdaftar, tanah yang terdaftar seperti: Hak Milik, Hak Guna Bangunan, Hak Guna Usaha, Hak Pakai, sedangkan tanah yang tidak terdaftar seperti: Girik, Petuk, Letter C.

Menurut Undang-Undang Nomor 21 Tahun 2008 tentang Perbankan Syariah, Pembiayaan adalah penyediaan tagihan atau dana yang berupa transaksi jual beli dalam bentuk ijarah dan ijarah muntahiya bittamlik, transaksi bagi hasil dalam bentuk Mudharabah dan Musyarakah, transaksi pinjam meminjam dalam bentuk qardh (Undang-Undang Nomor 21 Tahun 2008). ${ }^{14}$ Pengikatan Hak Tanggungan (HT) dapat pula didasarkan atas sertifikat Hak Milik dari Satuan Rumah Susun (Sarusun) berdasarkan ketentuan pasal 47 ayat 5

${ }^{14}$ Vitasari Diana, Prosedur Pembiayaan Musyarakaha pada BMT Batik Mataram, Program Diploma III Fakultas Ekonomi Universitas Islam Indonesia, Yogyakarta, 2018, h. 10. 
Undang-Undang Nomor 20 Tahun 2011, pasal 47 ayat 5 Surat Hak Milik sarusun dapat dijadikan jaminan utang dengan dibebani Hak Tanggungan (HT) sesuai dengan ketentuan peraturan perundangundangan. ${ }^{15}$

Pembebanan Hak Tanggungan atas tanah/obyek yang menjadi jaminan utang sangat diperlukan. Hal ini sebagai jaminan bila Debitur cidera janji atau gagal membayar utangnya, maka Bank bisa langsung mengeksekusi tanah atau obyek yang menjadi jaminan utang tersebut. Namun eksekusi jaminan tersebut harus diletakkan dulu Hak Tanggungan sehingga bisalangsung dieksekusi. Adapun prosedur Pengikatan Hak Tanggungan atas tanah sebagai berikut:

\section{Implementasi Prinsip-Prinsip} Syariah dalam Pengikatan Hak Tanggungan pada Pembiayaan Musyarakah PT BNI Syariah di

\section{Kota Banda Aceh.}

Perikatan Syariah dan jaminan Syariah merupakan 2 (dua) entitas Hukum yang tidak dapat dipisahkan. Keberadaan jaminan Syariah baru timbul setelah adanya Perikatan Syariah. Hal ini jika dianalogkan dengan konsep dalam Hukum perdata, maka jaminan merupakan perjanjian ikutan (accesoir) sedang perikatan Syariah

\footnotetext{
Hasil Wawancara dengan Ichwan Hassafa, Processing, di PT BNI Syariah Kota Banda Aceh, Jumat, 25 September 2019, Jam 11.00 WIB.
}

perjanjian pokok. ini asas Hukum yang melandasi perikatan Syariah, secara mutatis mutandis dapat diberlakukan juga sebagai asas Hukum jaminan Syariah

Salah satu model untuk menemukan asas Hukum adalah apa yang disampaikan oleh Paul Scholten dalam usaha untuk mencari makna suatu peraturan, mulai dengan mengangkat suatu peraturan Hukum kepada timgkat yang lebih tinggi, yang umumnya dikenal sebagai kegiatan mencari ratio legisnya. Dari penarikan kepada tingkatan yang lebih tinggi dapat menemukan pengertian yang lebih luas, lebih umum jangkauannya dari yang semula. ${ }^{16}$

a. Al Huriyah (Asas Kebebasan)

Al- Hurriyah (kebebasan) dan AlMas'uliyah (Tanggung Jawab) termasuk dalam Prinsip Ekonomi Islam. Prinsip AlHurriyah (kebebasan) merupakan kegiatan ekonomi yang di lakukan seseorang menikmati sepenuhnya kebebasan dalam berfikir dan bertindak. Kebebasan itu merupakan tindakan-tindakan terpuji dan dapat merasakan sesungguhnya di suatu negara Islam. Prinsip kebebasan ini untuk melakukan kegiatan perekonomian seperti mengolah,

16 Purnamasari Devita Irma, Hukum Jaminan Perbankan, PT Mizan Pustaka, Bandung, 2011, h. 80. 
mendistribusikan kekayaan alam seperti kekayaan laut dan di darat, contohnya pertanian, perikanan, perkebunan, dan bisnis ekonomi yang lain. $^{17}$

b. Al Musawah (Asas Persamaan dan Kesetaraan)

Pengertian Musawah adalah persamaan semua manusia dalam konteks hak dan kewajiban. Sementara Tasamuh artinya adalah menghargai perbedaan yang ada sesuai dengan batasan Syariat. Terakhir yang dimaksud dengan Ta'awun adalah saling tolong menolong antara sesama. ${ }^{18}$

c. Al Adalah (Asas Keadilan)

Al-'Adl artinya Maha Adil. Al-'Adl berasal dari kata 'adala yang berarti lurus dan sama. Keadillan Allah SWT bersifat mutlak, tidak dipengaruhi oleh apapun dan oleh siapapun. Allah mengetahui apa yang terbaik bagi makhluknya. Hanya Allah yang mengetahui nasib kita. Perwujudan dari nasib itu adalah keadilannya.

d. Al Ridha (Asas Kerelaan)

\footnotetext{
${ }^{17}$ Nur Fitriyah, Al Huriyah dan Al Masuliyah dalam Ekonomi Islam, https://www.kompasiana.com, Diakses Tanggal 10 Oktober 2019, Jam 10.00 WIB.
}

18 Husein Muhammad, Tafsir of Al Hurriyah, Al Musawah, Al Karamah and Al Adalah, Jurnal perempuan, Jakarta, 2014, Volume 3 Nomor 1, h. 191.
Ridha merupakan salah satu akhlak terpuji. Pengertian Ridha menurut bahasa adalah suka rela dan senang. Ridha artinya sudah merasa cukup dengan apa yang dimiliki, baik harta maupun pekerjaan.

e. Ash Shidq (Asas Kejujuran dan Kebenaran)

Shidiq (ash-sidqu) artinya benar atau jujur, lawan dari dusta atau bohong (al-kazib). Seorang muslin dituntut selalu berada dalam keadaan benar lahir batin; benar hati (shidq alqalb), benar perkataan (shidq alhadits), dan benar perbuatan (shidq al-'amal). Antara hati dan perkataan harus sama tidak boleh berbeda, apalagi antara perkataan dan perbuatan. Rasulullah saw memerintahkan setiap Muslim untuk selalu shidiq, karena sikap shidiq membawa kepada kebaikan, dan kebaikan akan mengantarkan ke surga. Sebaliknya beliau melarang umatnya berbohong, karena kebohongan akan membawa kepada kejahatan dan kejatahan akan berakhir di neraka.

f. Al Kitabah (Asas Tertulis)

Di dalam kaitannya dengan konteks jaminan menurut Prinsip Al Kitabah ini, perjanjian antara Nasabah dengan Bank harus dilakukan secara tertulis. 
Tidak hanya tertulis dan dibawah tangan, tetapi malah harus dilakukan dihadapan Notaris dalam bentuk otentik. Undang-Undang mewajibkan Hak Tanggungan untuk didaftarkan.

Untuk mengelaborasi Prinsip Hukum jaminan Syariah dengan menggunakan metode induksi, maka terlebih dahulu harus dipahami aturan Hukum tentang jaminan Syariah, dicari pengertian-pengertian yang lebih umum sifatnya, yaitu Prinsip Hukum jaminan Syariah. ${ }^{19}$

\section{Gambaran Umum PT Bank Negara Indonesia Syariah Kota Banda Aceh}

BNI Syariah adalah lembaga perbankan di Indonesia. Bank ini semula bernama Unit Usaha Syariah Bank Negara Indonesia yang merupakan anak perusahaan PT BNI, Persero, Tbk, sejak 2010, Unit Usaha BNI Syariah berubah menjadi bank umum Syariah dengan nama PT Bank Negara Indonesia Syariah.

Disamping itu nasabah juga dapat menikmati layanan syariah di Kantor Cabang BNI Konvensional (office channeling) dengan lebih kurang 1500 outlet yang tersebar diseluruh wilayah Indonesia. Di dalam pelaksanaan operasional perbankan, BNI Syariah tetap memperhatikan kepatuhan terhadap aspek Syariah. dengan Dewan Pengawas Syariah
(DPS) yang saat ini diketuai oleh KH.Ma'ruf Amin, semua produk BNI Syariah telah melalui pengujian dari DPS sehingga telah memenuhi aturan Syariah.

2. Implementasi Prinsip Syariah dalam Pembiayaan Musyarakah

Prinsip-Prinsip Syariah dalam Pembiayaan Musyarakah sebagian sudah terimplementasi dan sebagiannya lagi belum terlihat pada Akad Pembiayaan Musyarakah di PT Bank Negara Indonesia Syariah Kota Banda Aceh yaitu:

a. Akad bebas Riba

Prinsip ini sudah terimplementasi di Akad Pembiayaan Musyarakah pada pasal 9 (sembilan) point ke-2 (dua) yang isinya apabila nasabah dengan sengaja atau karena kelalaian terlambat atau tidak melakukan pembayaran kewajiban maka nasabah dikenakan ganti rugi sebesar 100\% (seratus persen) dari jumlah kerugiaan riil yang diderita Bank, selanjutnya pada pasal 10 (sepuluh) point ke-2 (dua) yang isinya jika menurut bank nilai agunan telah menurun dibandingkan dengan nilai dan harga yang dipakai dalam taksasi semula, maka atas pemberitahuan bank, nasabah wajib menambah barang yang diagunkan;

b. Akad bebas Maisir

${ }^{19}$ Noor Hafidah, Op. Cit, h. 80. 
Prinsip ini sudah terimplementasi di Akad Pembiayaan Musyarakah pada pasal 7 (tujuh) point ke-2 (dua) yang isinya ketentuan nisbah sebagaimana disebutkan dalam ayat 1 pasal ini adalah berdasarkan hasil usaha sesuai dengan laporan keuangan nasabah dan nisbah ini dapat diubaj sewaktuwaktu;

c. Akad bebas Gharar

Prinsip ini belum terimplementasi di Akad Pembiayaan Musyarakah pada pasal 10 point ke-1 (satu) yang isinya guna lebih menjamin pembayaran kembali kewajiban nasabah berdasarkan akad ini, nasabah menyerahkan agunan kepada bank yang dalam hal ini merupakan barang milik dari nasabah yang tidak dikategorikan dalam gharar;

d. Akad bebas unsur Haram

Prinsip ini sudah terimplementasi di Akad Pembiayaan Musyarakah pada pasal 9 (Sembilan) point ke 2 (dua) yang isinya yaitu apabila nasabah dengan sengaja atau karena kelalaian terlambat atau tidak melakukan pembayaran kewajiban maka nasabah dikenakan ganti rugi sebesar 100\% (seratus persen) dari jumlah kerugiaan riil yang diderita Bank, selanjutnya pada pasal 10 (sepuluh) point ke-2 (dua) yang isinya jika menurut bank nilai agunan telah menurun dibandingkan dengan nilai dan harga yang dipakai dalam taksasi semula, maka atas pemberitahuan bank, nasabah wajib menambah barang yang diagunkan yang dalam hal ini merupakan haram dengan tidak merujuk pada prinsip-prinsip syariah; atau

\section{e. Akad bebas Kedzaliman}

Prinsip ini sudah terimplementasi di Akad Pembiayaan Musyarakah pada pasal 9 (Sembilan) point ke 2 (dua) yang isinya yaitu apabila nasabah dengan sengaja atau karena kelalaian terlambat atau tidak melakukan pembayaran kewajiban maka nasabah dikenakan ganti rugi sebesar 100\% (seratus persen) dari jumlah kerugiaan riil yang diderita Bank, selanjutnya pada pasal 10 (sepuluh) point ke-2 (dua) yang isinya jika menurut bank nilai agunan telah menurun dibandingkan dengan nilai dan harga yang dipakai dalam taksasi semula, maka atas pemberitahuan bank, nasabah wajib menambah barang yang diagunkan dan dengan demikian kategori 2 (dua) pasal diatas masuk dalam kategori zalim dikarenakan adanya ketidakadilan bagi pihak nasabah dalam ketentuan 
yang dibuat oleh pihak bank dalam akad pembiayaan musyarakah.

3. Implementasi Prinsip Syariah dalam Pengikatan Hak Tanggungan

Bahwa Akta Pemberian Hak Tanggungan sebagian sudah terimplementasi dan sebagiannya belum terlihat pada prinsip Syariah yang diikat dengan Hak Tanggungan di PT Bank Negara Indonesia Kota Banda Aceh.

a. Al Mikul Mutlak/Prinsip Absolut Mutlak

Prinsip ini sudah terimplementasi di Akta Pemberian Hak Tanggungan pada resital sebelum Pasal 1 yang isinya sertipikat dan bukti pemilikan yang disebutkan diatas diserahkan kepada saya, PPAT, untuk keperluan pendaftaran hak, pendaftaran peralihan hak, dan pendaftaran Hak Tanggungan yang diberikan dengan akata ini, pemberian Hak Tanggungan tersebut di atas meliputi juga segala perlengkapan yang menjadi satu, lesatuan diatas tanah terutama satu unit bangunan, baik yang sekarang telah ada maupun yang aka nada dikemudian hari yang sifatnya dan peruntukannya atau menurut undang-undang termasuk bilangannya yang dapat dianggap barang tidak bergerak, untuk selanjutnya ha katas tanah/ hak milik atas satuan rumah susun dan bendabenda lain tersebut diatas disebut sebagai obyek Hak Tanggungan yang oleh pihak pertama dinyatakan sebagai miliknya, para pihak dalam kedudukannya sebagaimana tersebut di atas menerangkan, bahwa pemberian Hak Tanggungan tersebut disetujui dan diperjanjikan dengan ketentuan -ketentuan.

b. Mabda Al Imtiyaz/Prinsip Preferen Prinsip ini belum terimplementasi atau belum terlihat jelas di Akta Pemberian Hak Tanggungan pada pasal 2 (dua) titik ke-10 (sepuluh) yang isinya Pihak Pertama akan mengasuransukan Obyek Hak Tanggungan terhadap bahaya-bahaya kebakaran dan malapetaka lain yang dianggap perlu oleh Pihak Kedua dengan syarat-syarat untuk suatu jumlah pertanggungan yang dipandang cukup oleh Pihak Kedua perusahaan asuransi yang ditunjuk oleh Pihak Kedua.

c. Mabda Mamluk Lil Rahin/Prinsip Spesialitas

Prinsip ini sudah diterapkan di Akta Pemberian Hak Tanggungan pada resital sebelum Pasal 1 yang isinya oleh pihak pertama diberikan dengan Akta ini kepada dan untuk kepentingan pihak kedua, yang 
dengan ini menyatakan menerimanya, Hak Tanggungan dan peraturan peraturan pelaksanannya atas Objek / Objek-objek berupa 1 (satu) Hak atas tanah / Hak atas tanah/ Hak Milik Atas Satuan rumah yang diuraikan.

\section{d. Mabda Al Qabdh/Prinsip Inbezitsteling}

Prinsip ini sudah terimplementasikan di Akta Pemberian Hak Tanggungan pada Pasal 2 yang isinya dalam hal debitor sungguh-sungguh cidera janji, pihak kedua oleh pihak pertama dengan akta ini diberi dan menyatakan menerima kewenangan, dan untuk kuasa, untuk mengelola Obyek Hak Tanggungan berdasarkan penetapan ketua Pengadilan Negeri yang daerah hukumnya meliputi letak obyek Hak Tanggungan yang bersangkutan

e. Mabda Faktubula/Prinsip Publisitas Prinsip ini jelas sudah terimplementasikan di Akta Pemberian Hak Tanggungan pada pasal 2 yang isinya sertipikat tanda bukti hak atas tanah yang menjadi Obyek Hak Tanggungan akan diserahkan oleh pihak pertama kepada pihak kedua untuk disimpan dan dipergunakan oleh pihak kedua dalam melaksanakan hak-haknya sebagai pemegang Hak Tanggungan dan untuk itu pihak pertama dengan akta ini memberikan kuasa kepada pihak kedua untuk menerima sertifikat tersebut dari kantor pertanahan setelah Hak Tanggungan ini didaftar.

\section{Akibat Hukum dalam Pengikatan} Hak Tanggungan pada Pembiayaan Musyarakah PT BNI Syariah di Kota Banda Aceh.

Akibat Hukum pihak yang menjamin (Nasabah/penanggung) itu timbulnya hak-hak dari Nasabah (Penanggung). Dalam melaksanakan kewajiban oleh Undang-Undang penanggung diberikan hak-hak tertentu yang sifatnya memberikan perlindungan bagi si penanggung. Hak-Hak penanggung tersebut menurut ketentuan UndangUndang berupa:

a. Hak untuk menuntut lebih dahulu (voorrecht van uitwinning)

b. Hak untuk membagi hutang (voorrecht van schuldsplitsing)

c. Hak untuk mengajukan tangkisan gugat (ps. 1849, 1850 KUH Perdata)

d. Hak untuk diberhentikan dari penanggungan (karena terhalang melakukan subrogasi akibat perbuatan kesalahan kreditur).

e. Hak untuk menuntut lebih dahulu

Dalam hal Nasabah lalai memenuhi prestasi, si penanggung baru wajib 
membayar hutang kepada Bank setelah menuntut agar harta benda Nasabah lebih dahulu disita dan dilelang/dijual untuk melunasi hutangnya (ps.1831 KUH Perdata). Jadi si penanggung baru wajib bertindak sebagai barang jika barangbarang Nasabah setelah disita dan dijual lebih dahulu, namun tidak mencukupi untuk membayar hutang.

Kewajiban Nasabah

a. Mengisi dan menandatangani formulir yang disediakan oleh Bank, sesuai dengan layanan jasa yang diinginkan oleh Nasabah

b. Melengkapi persyaratan yang telah ditentukan oleh Bank

c. Membayar Provisi yang telah ditentukan oleh Bank

d. Menyetor dana awal yang telah ditentukan oleh Bank

Menyerahkan buku cek/giro bilyet tabungan

Akibat Hukum terhadap pihak yang meminta jaminan (Bank) menimbulkan Hak dan Kewajiban yaitu:

1. Hak Bank

a. Menerima pengembalian sampai lunas sesuai dengan syarat yang diperjanjikan

b. Menguasai barang jaminan

c. Syirkah berhak setiap waktu memeriksa semua harta benda yang dijaminkan kepada Bank untuk hutangnya atau yang diserahkan kepadanya secara Hak Tanggungan

d. Mengambil barang yang dijaminkan Syirkah apabila Syirkah tidak mampu melunasi kreditnya

\section{Kewajiban Bank}

a. Memberikan dana sesuai yang tercantum dalam surat perjanjian kredit

b. Menyerahkan surat bukti kepemilikan barang jaminan apabila kredit lunas

Kewajiban yang lahir terhadap Pihak yang menjamin ada dalam pasal 1 (satu) yang isinya Pihak Pertama menjamin bahwa semua Obtek Hak Tanggungan tersebut diatas, betul milik Pihak Pertama, tidak sersangkut dalam suatu sengketa, bebas dari sitaan dan bebas pula dari bebanbeban apapun yang tidak tercatat.

Diikatkan suatu Objek dengan Hak Tanggungan, tentu saja akan memiliki Akibat Hukum terhadap Objek yang diikatkan tersebut, dalam hal ini adalah Tanah. Tanah dan bangunan yang diikatkan Hak Tanggungan dikuasi oleh bank yang memberikan kredit, sehingga apabila terjadi kredit macet, Bank berhak untuk mengeksekusi Objek Jaminan tersebut dengan cara dilelang dalam rangka untuk mengganti sisa utang dari nasabah yang macet, selain itu dengan diikatnya Objek Hak Tanggungan, sertifikat Tanah tersebut akan ditahan dan disita oleh Bank yang 
bersangkutan, sehingga Banklah yang akan Bertanggung Jawab apabila terjadi kerusakan/hilangnya sertifikat tanah tersebut.

Pada umumnya walaupun telah diikatkan dengan Hak Tanggungan kepemilikan Objek Jaminan masih berhak pada Nasabah. Hanya saja Nasabah tidak boleh melakukan tindakan mengalihkan/menjual dengan sesukanya, karena apabila akan melakukan tindakan menjual, harus melunasi utang yang masih ada di Bank, dan selama masa diikatkan Hak Tanggungan, apabila terjadi kerusakan atas Objek yang ada dalam sertifikat Tanah tersebut menjadi Tanggung Jawab Nasabah sendiri, karena Nasabah itu masih menggunakan Objek yang diagunankan tersebut. Seperti Tanah.

Jadi Pengikatan Hak Tanggungan tersebut hanyalah sebagai jaminan agar si Nasabah merasa masih memiliki Tanggung Jawab terhadap Bank yang telah memberikan kredit kepada Nasabah itu.

\section{E. Kesimpulan dan Saran}

\section{Kesimpulan}

a. Ketentuan Hukum Pengikatan Hak Tanggungan di Indonesia diatur dalam Undang-Undang Nomor 4 Tahun 1996 tentang Hak Tanggungan yaitu tercantum pada pasal 1 (satu) yang isinya pengertian Hak Tanggungan adalah hak jaminan yang dibebankan, kemudian pada pasal 4 (empat) sampai dengan 7 (tujuh) mengenai Obyek Hak Tanggungan, kemudian pada pasal 8 (delapan) dan 9 (Sembilan) tentang pemberi dan pemegang Hak Tanggungan, kemudian pada pasal 17 (tujuh belas) berisi tentang bentuk dan isi Akta Pemberian Hak Tanggungan dan terakhir pada pasal 18 (delapan belas) yang isinya hapusnya Hak Tanggungan.

b. PT BNI Syariah Kota Banda Aceh menerapkan Prinsip-Prinsip Syariah dalam Pengikatan Hak Tanggungan pada Akad Pembiayaan Musyarakah seperti Prinsip Mabda Al Mikul Mutlak, Mabda Al Imtiyaz, Mabda Mamluk Lil Rahin, Mabda Al Qabth, dan Mabda Faktubula. Berdasarkan penerapan Prinsip Prinsip Syariah tersebut, sebagian telah diterapkan (Mabda Al Mikul Mutlak, Mabda Mamluk Lil Rahin, Mabda Al Qabth, dan Mabda Faktubula) dan sebagian belum diterapkan (Mabda Al Imtiyaz).

c. Akibat Hukum yang timbul pada Pengikatan Hak Tanggungan dalam Musyarakah pada PT BNI Syariah Kota Banda Aceh yang meliputi Akibat Hukum terhadap Obyek jaminan yang tetap dimiliki oleh Nasabah namun dikuasai oleh Bank, Pihak yang memberi jaminan Hak Nasabah seperti 
Hak untuk menuntut lebih dahulu, kewajibannya membayar provisi yang telah ditentukan oleh Bank, dan Pihak yang meminta jaminan Hak Bank seperti menerima pengembalian sampai lunas sesuai dengan syarat yang diperjanjikan, kewajibannya memberikan dana sesuai dengan yang tercantum dalam surat perjanjian kredit.

\section{F. Daftar Pustaka}

\section{Buku}

Abdullah, Burhanuddin, 2003, Peran kebijakan Moneter dan Perbankan dalam Mengatasi Krisis Ekonomi di Indonesia, Buku Pedoman Angkatan XXXVI Lemhanas, Jakarta.

Abdul, Ghofur, Anshori, 2009, Hukum Perbankan Syariah (Undang-Undang Nomor 21 Tahun 2008, PT Refika Aditama, Bandung.

Abdul, Manan, 2001, Penerapan Hukum Acara Perdata Di Lingkungan Peradilan Agama, Yayasan Al-Hikmah, Jakarta.

Adiwarman, Karim, 2004, Bank Islam; Analisis Fiqih dan Keuangan, PT Raja Grafindo Persada, Jakarta.

Adittya, Septian, Hermawan, 2012, Buku Standar Operasional Musyarakah, Otoritas Jasa Keuangan Syariah, Jakarta.

Ahmad, Dimyati, 1994, Sejarah Lahirnya BAMUI, Dalam Arbitrase Islam Indonesia, Badan Arbitrase Islam Diindonesia, Badan Arbitrase Muamalat Indonseia Kerja Sama dengan Bank Muamalat Indonesia, Jakarta.

Ahmad, Fuad, 2005, Pengaturan Perbankan Syariah Dalam Sistem Peraturan PerundangUndangan Nasional, Dalam Majalah Hukum Nasional Nomor 1 Tahun 2005, Badan Pembinaan Hukum Nasional Departemen Kehakiman, Jakarta.

Ahmad, Warson, Munawwir, 1997, Kamus Arab Indonesia Al Munawwir, Cet Keempat, Jakarta.

Amran, Suadi, 2015, Penyelesaian Sengketa Ekonomi Syariah, Teori Dan Praktek, Petunjuk Pelaksanaan Lelang yang Ditenggarai Menjadi Penyebab Banyaknya Bank yang Melakukan Lelang Tanpa Adanya Fiat Pengadilan, Jakarta.

Aries, Kartono, Avantiono Hadhianto, 2009, Perbankan Syariah perspektif Praktisi, Muamalat Insitute, Jakarta.

A, Rahmat, Rosyadi, and Ngatino, 2002, Arbitrase Dalam Perspektif Islam dan Hukum Positif, Pt Citra Aditya Bakti, Bandung. 
Ascarya, 2015, dan Produk Bank Syariah, PT RajaGrafindo Persada, Jakarta.

Badrulzaman, Mariam, 2001, Kompilasi Hukum Perikatan, PT Citra Aditya, Bandung. Bambang, Sunggono, 2006, Metodologi Penelitian Hukum, PT Rajagrafindo Persada, Jakarta.

Boedi, Harsono, 2008, Hukum Agraria Indonesia, Sejarah Pembentukan Undang-Undang Pokok Agrarian Isi dan Pelaksanaanya, Djambatan, Jakarta.

Crano, Willian, D, and Brewer, Marilyn, B, Lowrence, Erlbaum, Assiciates, 2002, Principles And methodes Of Social Research, Mahwah Publishers New Jersey.

Dahlan, Siamat, 2004, Manajemen lembaga Keuangan Edisi Ketiga, Lembaga penerbit Fakultas Ekonomi Universitas Indonesia, Depok.

Gemala, Dewi, 2007, Bank Syariah Di Indonesia, Sinar Grafika, Jakarta.

Hasan, Iqbal, 2002, Pokok-Pokok Materi Metodologi Penelitian dan Aplikasinya, Ghalia Indonesia Bogor.

Hasanuddin, Rahman, Daeng, Naja, 2005, Hukum Kredit dan Bank Garansi: Bankers Hand Book, PT Citra Aditya Bakti, Bandung.

Haposan, Rudi, 2017, Hukum Perikatan Indonesia Teori dan Perkembangannya, C.V Cita Intrans Selaras, Malang.

Hendry, Arisson, Kartono Aries, Hadhianto Avantiono, Yudhoko Aryo, 1999, Perbankan Syariah, Muamalat Institute, Jakarta.

Hirsanuddin, 2008, Hukum Perbankan Syariah di Indonesia, Genta Press, Yogyakarta.

Jaih, Mubarok, Hasanuddin, 2015, Prinsip-Prinsip Perjanjian, PT Rajagrafindo Persada, Jakarta.

Jeni, Susyanti, 2018, Pengelolaan Lembaga Keuangan Syariah, PT Rajagrafindo Persada, Jakarta.

J, Satrio, 2017, Hukum Jaminan, Hak Jaminan Kebendaan, Hak Tanggungan, Citra Aditya, Bandung.

Kamello, Tan, 2004, Hukum Jaminan Fidusia, Suatu Kebutuhan yang Didambakan, Alumni, Bandung.

Kansil, Christine, S.T, 1997, Pokok-Pokok Hukum Hak Tanggungan Atas Tanah, Pustaka Sinar Harapan, Jakarta.

Mardani, 2009, Hukum Acara Perdata Peradilan Agama dan Mahkamah Syariah, CV Sinar Grafika, Jakarta.

M, Bahsan, 2007, Hukum Jaminan Kredit, PT Rajagrafindo Persada, Jakarta. 
Muhammad, 2014, Perbedaan Bank Syariah Dan Bank Konvensional, Sinar Grafika, Jakarta. Muhammad, 2015, Manajemen dana Bank Syariah, PT RajaGrafindo Persada, Jakarta.

Muhammad, Syafii, Antonio, 2000, Bank Syariah Dari Teori ke Praktik, Gema Insani, Jakarta.

Muh, Zuhri, 1996, Riba dalam Alquran dan Masalah Perbankan (Sebuah Tilikan Antisipatif), Rajagrafindo Persada, Jakarta.

Mujahidin, Akhmad, 2016, Hukum Perbankan Syariah, PT RajaGrafindo Persada, Jakarta.

Muljadi, Kartini, dan Widjaja, Gunawan, 2005, Seri Hukum Harta Kekayaan Hak Tanggungan, Prenada Media, Jakarta.

Munir, Fuady, 2014, Konsep Hukum Perdata, RajaGrafindo Persada, Jakarta.

Munir, Fuady, 2013, Hukum Jaminan Utang, Erlangga, Jakarta.

Nasrun, Haroen, 2000, Fiqh Muamalah, Gaya Media Pratama, Jakarta.

Poerwadarminta, W,J,S, 1985, Kamus Umum Bahasa Indonesia, Balai Pustaka, Jakarta.

Said, Agil, Husen, Munawar, 1994, Pelaksanaan Arbitrase di Dunia Islam, Dalam Arbitrase Islam di Indonesia, Badan Arbitrase Muamalat Indonesia Kerja Sama dengan Bank Muamalat Indonesia, Jakarta.

Salim, HS, 2015, Perkembangan Hukum Jaminan di Indonesia, PT RajaGrafindo Persada, Jakarta.

Sembiring, Rosnidar, 2017, Hukum Pertanahan Adat, PT RajaGrafindo Persada, Depok.

Simorangkir, J, 2007, Kamus Hukum, Sinar Grafika, Jakarta.

Singarimbun, Masri, dkk, 1999, Metode Penelitian Survey, LP3ES, Jakarta.

S, HR, Otje, Salman, dan F, Susanto, Anton, 2005, Teori Hukum, Refika Aditama, Bandung.

Sulthoni, Muhdali, 2018, Eksekusi Putusan Pengadilan Agama Tentang Hak Tanggungan Dalam Perkara Ekonomi Syariah, Penyelesaian Sengketa Ekonomi Syariah, Penemuan dan Kaidah Hukum, Kencana, Jakarta.

S,T, Sjahdeini, Remy, 1999, Hak Tanggungan Asas-Asas, Ketentuan-Ketentuan, Pokok dan Masalah yang Dihadapi oleh Perbankan, Alumni, Bandung.

Sunarto, 2014, Peran Hakim dalam Perkara Perdata, Kencana, Jakarta.

Supranto, J, 2003, Metode Penelitian Hukum dan Statistik, Rineka Cipta, Jakarta.

Supriyadi, 2015, Dasar-Dasar Hukum Perdata di Indonesia, Kiara Science, Kudus.

Suryabrata, Sumandi, 1998, Metodologi Penelitian, Rajagrafindo Persada, Jakarta.

;Syamsul, Anwar, 2010, Hukum Perjanjian Syariah Studi tentang Teori dalam Fikih Muamalah, Rajawali Pers, Jakarta. 
Thaib, Hasballah, M, dan Zamakhsyari, 2017, Jaminan Dalam Pembahasan Hukum Islam, Buku Ajar Magister Kenotariatan Sekolah Pasca Sarjana Universitas Sumatera Utara, Medan.

Umam, Khotibul, dan Utomo, Budi, Setiawan, 2018, Dasar-dasar dan Dinamika Perkembangannya di Indonesia, Perbankan Syariah, PT RajaGrafindo Persada, Jakarta.

Usman, Rachmadi, 2009, Produk dan Pembiayaan Syariah di Indonesia: Implementasi dan Aspek Hukum, PT Citra Aditya Bakti, Bandung.

Usman, Rachmadi, 2013, Hukum Kebendaan, Sinar Grafika, Jakarta.

Usman, Rachmadi, 2014, Aspek Hukum Perbankan Syariah, diindonesia, Sinar Grafika, Jakarta.

Vitasari, Diana, 2018, Prosedur Pembiayaan Musyarakaha pada BMT Batik Mataram, Program Diploma III Fakultas Ekonomi Universitas Islam Indonesia, Yogyakarta.

Wirartha, Made, 2005, Pedoman penulisan usulan penelitian, skripsi, dan Tesis, CV. Andi Offset, Yogyakarta.

Wirdyaningsih, 2005, Et.Al, Bank dan Asuransi Islam Di Indonesia, Kencana Predana Media dan Badan Penerbit Fakultas Hukum Universitas Indonesia, Jakarta.

Yahya, 2007, M, Harahap, Ruang Lingkup Permasalahan Eksekusi Bidang Perdata, Sinar Grafika, Jakarta.

Zainuddin, Ali, 2008, Hukum Perbankan Syariah, CV Sinar Grafika, Jakarta.

Zainul, Arifin, 1999, Memahami Bank Syariah, Pustaka Alvabet, Jakarta.

Zubairi, Hasan, 2009, Undang-Undang Perbankan Syariah Titik Temu Hukum Islam dan Hukum Nasional, Rajawali Pers, Jakarta.

\section{Jurnal}

Aam Slamet Rusydiana, 2016, Analisis Masalah Pengembangan Perbankan Syariah di Indonesia: Aplikasi Metode Analytic Network Process, esensi, Volume 6 (2)

Aminah Lubis, 2016, Aplikasi Murabahah Dalam Perbankan Syariah, Fitrah, Volume 02 No. 2

Ardani Novana Mira, 2017, Fungsi Surat Kuasa Membebankan Hak Tanggungan Ditinjau dari Ketentuan Pasal 15 Undang-Undang Nomor 4 Tahun 1996, Jurnal Fakultas Hukum Universitas Diponegoro, Semarang, Volume 1 Nomor 1.

Entaresmen Ajeng Raden, dan Pertiwi Putri Desy, 2017, Strategi Pemasaran Terhadap Penjualan Produk Tabungan IB Hasanah di PT. Bank Negara Indonesia Syariah Kantor Cabang Jakarta Barat, Jurnal Manajemen dan Pemasaran Jasa, Volume 9 No. 1 
Erika Amelia, 2017, Determinant of Mudharabah Financial: A Study At Indonesian Islamic Rural Banking, Etikonomi, Volume 16 (1)

Irfan Taufik Sholihin, 2018, Kebijakan Jaminan Fidusia pada Pembiayaan Murabahah di Bank Syariah Mandiri Kantor Cabang Pembantu Merdeka Bogor, Jurnal Nisbah, Volume 4 No. 2

Kartika Fatma Rini, 2016, Jaminan Dalam Pembiayaan Syariah (Kafalah dan Rahn), Jurnal Komunikasi Antar Perguruan Tinggi Agama Islam, Volume 15 No.2

Muhammad Abduh, 2011, International Journal of Excellence in Islamic Banking and Finance, Issn, Volume 1-Issue 2

Mushaffa Zaky Muhammad, Hanim Lathifah, 2017, Peranan Notaris dalam Pengikatan Agunan dengan Hak Tangungan (Studi Kasus Pada KSPPS BMT Bahtera Kota Pekalongan), Jurnal, Volume 4 Nomor 1

Nurjannah ST, 2018, Eksistensi Hak Tanggungan Sebagai Lembaga Jaminan Hak Atas Tanah

(Tinjauan Filosofis), Jurnal Universitas Islam Negeri (UIN) Alauddin Makassar, Volume 5 No. 1

Permanasari Santi Ayu Ida, dan Darma Sri Gede, 2013, Pengaruh Penggunaan Internet Banking Terhadap Rasa Aman, Rasa Percaya dan Loyalitas Nasabah Dalam Meningkatkan Saldo Bank, Jurnal Manajemen dan Bisnis, Volume 10 No.1

Prabawa Artha Andi Gede Bagus, 2017, Bentuk Pengikat jaminan dan Penyelesaian Kredit Macet di Lembaga Perkreditan, Jurnal Fakultas Hukum, Hukum Bisnis, Universitas Udayana, Badung, Volume 1, Nomor 2

Trimulato, 2017, Analisis Potensi Produk Musyarakah Terhadap Pembiayaan Sector Riil UMKM, Jurnal Ekonomi dan Studi Pembangunan, Volume 18 No. 1

Wafa Ali Moh, 2017, Hukum Perbankan Dalam Sistem Operasional Bank Konvensional dan Bank Syariah, Jurnal Fakultas Syariah dan Hukum UIN Syarif Hidayatullah Jakarta, Volume XVI No 